\title{
The Development and Status of European Law
}

\author{
Joseph Straus
}

\section{INTRODUCTION}

At present the overall superiority of US biotechnology in science and industry is beyond all doubt. In the field of animal biotechnology, however, some US authors have suggested an apparent lead of two European countries, namely of the UK and the Republic of Ireland (Raines, 1988). Since during this symposium only US scientists will report on their achievements, a comparison between developments in Europe and the USA in the field of interest will not take place. Thus, it is not possible to find out whether or not such a statement is pure calculated pessimism in order to mobilize more intellectual and financial resources, and to provide a more favorable legal and social environment for animal biotechnology. Nonetheless, it seems to come close to the truth that at least some research groups in Europe are more or less keeping pace with US scientists in animal biotechnology (Brem et al., 1986; Clark et al., 1987; Land and Wilmut, 1987; McEvoy et al., 1987; Brem et al., 1988; Brem, 1988a; 1988b). This observation, however, could also indicate that scientists on both sides of the Atlantic are equally far away from their targets (Jaenisch, 1988).

Apart from the status of European law concerning the protection of results of animal biotechnology, which will be discussed more in depth below, Europe is, no doubt, lagging behind the USA in respect to investigations into the economic effects of biotechnology in agriculture in general, and more specifically in the field of animals and animal patenting. Until now Europe has completely relied on the work performed in the USA either by governmental $^{1}$ or private institutions (Board on Agriculture National Research Council, 1984; Teich et al., 1985; Committee on a National Strategy for Biotechnology in Agriculture, 1987) or by such distinguished scientists as the organizer of this symposium (Lesser, 1987; 1988). (For a more general discussion see Ruttan, 1982.) Whether Europe can afford such an indolence in the medium and long term seems doubtful in view of the fact that conditions governing the field of agriculture in Europe differ considerably from those in the USA. It is to be hoped, however, that free riding

1 All studies prepared under the auspices of the US Congress, Office of Technology Assessment (OTA) have formed the basis and starting point for nearly all pertinent European considerations. 
on the part of the Europeans will not provoke any new US action in the GATT.

Even if the Europeans were to lead in the field, this should not be a cause of serious concern. The USA should have learned from experience that a leading position in research in Europe in a particular scientific field does not necessarily result in its lead in innovation. One reason is the lack of patent protection for the processes and products in question. The most prominent example was the case of penicillin, where the more favorable patent situation in the USA, notwithstanding the previous UK lead, eventually resulted in the successful engagement of the US industry and in the necessity for royalty payments overseas for the national production of penicillin in the UK (Clark, 1985). If nothing happens in due time, Europe could well face a similar situation in respect to results of research into animal biotechnology.

\section{PECULIARITIES OF PAST EUROPEAN DEVELOPMENTS}

In order to provide for a better understanding of the main existing differences between the US patent law, as presented by Stephen Bent in his paper, and the European legal framework, as well as the problems arising from the protection of animal biotechnology results, it seems appropriate to reflect briefly on past developments.

Although neither the US patent law nor those of European countries originally provided for special provisions concerning inventions in the field of living matter, it was commonly understood that such inventions could not, as a rule, form patentable subject matter. Patent offices and courts in Europe, as well as in the USA, only gradually departed from that idea. Eventually, at least as far as the Federal Republic of Germany (FRG) is concerned, they expressly declared all inventions in the field of living matter, including animal-breeding processes and even animals per se, patentable (Beier et al., 1985: p. 22 et seq.; Straus, 1985: p. 51 et seq.). It is worth while mentioning that it was the German Federal Supreme Court which took the lead internationally when in 1969 it decided the well-known "Red Dove" (Rote Taube) case. $^{2}$ The key statement of this decision was that a technique in the field of biology could be considered patentable if it was shown to utilize controllable natural forces to achieve a causal, perceivable result. It was further required that this technique should meet the general patentability requirements and should be repeatable (i.e. it could be readily duplicated by others skilled in the art). Since the animal-breeding process claimed in the "Red Dove" case was not repeatable merely on the basis of a written description no patent was issued. Apart from the generally criticized repeatability requirement, this decision was well received. This was because it particularly broadened the concept of a patentable invention to encompass animal-breeding methods and animals per se. Unlike the 1980 Diamond v. Chakrabarty decision of the US

$2 \quad 1$ IIC 137(1970) 
Supreme Court and the recent grant of the Leder transgenic mouse patent by the US Patent and Trademark Office (Raines, 1988), the "Red Dove" decision was not followed by discussions devoted to either the ethical and moral aspects of patenting animals or to the possible economic effects of such patenting. Why this was not the case is difficult to answer, but it is probably due to the techniques used. In the "Red Dove" case the classical crossbreeding methods were employed, whereas in Diamond $v$. Chakrabarty, and even more so in the Leder case, a universally applicable technique (i.e. also applicable to humans) was at issue, namely that of recombinant DNA. It is primarily this collection of universally applicable new techniques labelled as genetic engineering, together with the lack of understanding of how the patent system works, that has created concern among the public when discussing the patenting of higher living organisms, especially animals.

The situation in the USA remained virtually unchanged until the introduction of the Animal Patent Bill (HR 4970) (Patent, Trademark and Copyright Journal, 1988a; 1988b): it was governed by case law with patent office practice following suit. In Europe, however, problems started to develop in the late 1950s and early 1960 s when countries decided to establish a special type of protection for new varieties of plants and to unify their patent laws. The first initiative resulted in the well-known International Convention for the Protection of New Varieties of Plants (UPOV Convention), signed in Paris in 1961. In Article 2 it introduced the so called prohibition of double protection (i.e. barring access to protection by plant variety rights and patents for one and the same botanical genus or species) (Straus, 1984; Adler, 1986). In view of current discussions in UPOV, Article 2 in the future could also play a role with regard to animals (UPOV, 1987). The second phase ended in the Convention on the Unification of Certain Points of Substantive Law on Patents for Inventions, established in 1963 (the Strasbourg Convention). That Convention in Article $2 \mathrm{~b}$ made it mandatory to protect microbiological processes and their resulting products, but left it to the discretion of the signatories as to whether or not to protect new plant or animal varieties and essentially biological processes employed in their production (Straus, 1985: para. 54; Commission of the European Communities, 1988: par 21 et seq.).

When the European Patent Convention (EPC) was adopted in 1973, it was decided that it could not impose obligations on contracting states other than those provided for under the Strasbourg Convention. The principles governing the UPOV and Strasbourg Convention were, therefore, introduced into the EPC without any serious reconsidering of developments which, in the meantime, had taken place in various areas of biotechnology, and which clearly demonstrated the distinction between micro- and macrobiology as an artificial one. Since that difference serves as the dividing line between mandatory patentable and discretionary patentable inventions in the Strasbourg Convention it is no longer tenable (Commission of the European Communities, 1988: Memo, part I, para. 25). 


\section{ACTUAL STATUS OF EUROPEAN LAW}

Resulting from the historical development in Western Europe, Article 53(b) of the EPC excludes from patent protection plant or animal varieties, as well as essentially biological processes for the production of plants or animals. Microbiological processes and their resulting products, however, are explicitly protected. In addition to Article 53(b), provisions of Articles 53(a) and 52(4) of the EPC are of decisive importance in this context. There is no disagreement that the exclusion by Article 53(a) of inventions, the publication or exploitation of which would be contrary to ordre public or morality is both necessary and useful. It guarantees that social and ethical considerations can be taken into account in the patent law system, which is otherwise neutral in its judgement and entirely devoted to the technological appreciation of inventions (Beier and Straus, 1986). In view of more recent developments in animal biotechnology (e.g. embryo recovery, embryo transfer, etc.), there is increased questioning of the general and undifferentiated exclusion of methods for treatment not only of the human, but also of the animal body by surgery or therapy, as laid down in Article 52(4) of the EPC (Straus, 1985: para. 73; Bent et al., 1987: pp. 162-63).

The situation that initially existed under the EPC was a logical and, at least in part, understandable consequence of previous international developments. It was aggravated and apparently made definitive when European countries, in the course of harmonizing their national patent laws with the EPC in the 1980s, took over the wording of Article 52(4) as well as that of Articles 53(a) and 53(b) of the EPC. This step left inventors in the field of traditional animal breeding without any possibility of protection. Other national issues such as in the FRG led to a questioning of the present status on constitutional grounds (von Pechmann, 1987: p. 347; Benkard, 1988: p. 205; Moufang, 1988: p. 218).

Although this paper is aimed at presenting the legal situation in Western Europe, for the sake of completeness it should be mentioned that a number of Eastern European countries expressly offer some sort of protection to ("traditional") animal breeders. Hungarian Patent Law of 1969 (as amended in 1983) provides for a UPOV-type protection for animal varieties under the conditions that they are:

(1) new in the sense of being different from known breeds in at least one essential characteristic (morphologically, physiologically, or in some other respect);

(2) homogeneous, i.e. identical in essential characteristics of their members;

(3) relatively stable, i.e. they may not deviate from their essential characteristics, as described in the patent, in the course of propagation by natural or artificial means or in the course of a propagatory cycle (Article 67 in connection with Article 31) (Cooper, 1985, pp. 6-14). 
Bulgaria, Rumania, and the USSR, on the other hand, issue so-called inventors' certificates to animal breeders. These certificates, however, do not secure for the inventor an exclusive right to exploit. Instead they only provide some moral rights and a title for remuneration (Pretnar, 1982: pp. 6-49; Moufang, 1988: p. 217).

\section{PROTECTION OFFERED UNDER THE EPC AND HARMONIZED EUROPEAN PATENT LAWS}

Prior to discussing the protection of the results of animal biotechnology offered under the EPC and the harmonized patent laws of Western European countries, it should be made quite clear that the EPC, although providing a system for granting European patents, does not secure uniform effects in designated states. Rather, European patents have, in each of the contracting states for which they are granted, the effect of-and are subject to the same conditions as-a national patent granted by that state (Articles 1 and 2 of the EPC). As is correctly stated in the Commission of the European Communities (1988) Memo on the Draft Directive, which will be considered later on (Beier, 1984: p. 54):

A European Patent is granted, defined and revoked in applying rules of the EPC, and to this extent, represents a collection of "European patents". For all other purposes, such as the scope of protection, European patents represent patents with national effects, subject to national laws, although certain minimum standards are prescribed in Articles 64(2) and 67 EPC.

It follows that the role of the European Patent Office (EPO) is to focus on the important but limited task of granting European patents. The interpretation and revocation of these patents are the responsibility of national authorities, who are not bound by the EPO practice, including its examination guidelines. Whatever the EPO and its executives decide, the patentability of the results of animal biotechnology will not necessarily remain valid in the contracting states. Past experience is, however, encouraging, since the case law in the FRG, Sweden, and the UK indicates that national courts are inclined to accept the EPO practice. ${ }^{3}$

Following the concept of the language of Article 53(b) of the EPC with

3 Following the practice of the EPO, the German Federal Supreme Court in 1987 revised its long-standing case law as regards the effects of deposits of microorganisms as substitute for enabling written disclosure: claims directed to biological material per se can now be based on deposits (Decision of February 12, 1987, 18 IIC 396 [1987]-Rabies Virus [Tollwutvirus] with comment of Geissler). Similarly the UK High Court of Justice, Patents Court (Decision of July 4 , 1985, [1985] R.P.C. $545=$ [1986] Off. J. EPO 175-Second Medical Use/Wyeth and Schering) and the Swedish Court of Patent Appeals (Decision of June 13, 1986, [1987], NIR $248=$ [1988] Off. J. EPO 196-Hydropyridine/SE) decided the question of patentability of inventions concerning a second medical use in the same way as the Enlarged Board of Appeals of EPO. 
regard to patentability of inventions in animal biotechnology, it seems advisable to distinguish between the following categories of inventions:

(1) animals and animal varieties per se;

(2) animals and animal varieties as products of a process;

(3) processes for the production of animals;

(4) animal material per se;

(5) processes for the production of animal materials.

Although there is no case law applying to the patentability of animals under the EPC, it has long been assumed that, in view of the parallel language for plant and animal varieties in Article 53(b), plants and animals are to be treated in exactly the same way. Since in respect to animals the problem of the prohibition of double protection does not exist, more flexibility exists in applying the patent system in a way that fulfills the legitimate interests of inventors (Teschemacher, 1987). Nonetheless a press release in June 1988 entitled "Patents for Living Matter?" indicated for the first time that the EPO, for ethical reasons, might view inventions in animals as being excluded from patentability under Article 53(a), the "morality" clause. Thus, it was said that Professor Leder, whose transgenic mouse application is pending with the EPO, might not be granted a patent. ${ }^{4}$

This general reference to Article 53(a) of the EPC and the idea that inventions in animals could be excluded from patentability for ethical reasons in general came as a surprise and are neither well founded nor in accordance with the original intention of the contracting states, at least as far as the European Community member states are concerned. During discussions on the draft of Article 29(c) of the Community Patent Convention (CPC), which deals with the prohibition of direct uses of inventions involving products directly obtained by a patented process, it became evident that although Article 53(b) excluded plant and animal varieties as such from patent protection, this exclusion could not be interpreted in a way as to leave unprotected plant and animal varieties as products directly obtained by a patented process. ${ }^{5}$ An interpretation of Articles 53(a) and (b) of the EPC in the way that would lead to a general exclusion of inventions in animals for ethical reasons can therefore hardly be correct.

Regarding the patentability of claims directed to animal varieties as such, as well as animal varieties produced by a patentable process, the solution is clear: both are excluded from patent protection. The latter are excluded, notwithstanding the fact that protection conferred by a patent for a process for the production of animals according to Article 64(2) of the EPC extends

4 The same concerns are expressed in a unpublished EPO document of September 6, 1988 (CA/H 6/88-III).

5 Preparatory documents no. 11 and 17, published in Records of the Luxembourg Conference on the Community Patent 1975, Luxembourg, 1981: pp. 32, 40, 41. See also Straus, 1987: p. 439. 
to animals, and even to animal varieties obtained by such process (Moufang, 1988: pp. 380, 381).

For the patentability of claims directed generally to animals and animal material, provided that the invention complies with all other patentability requirements, the answer should be in the affirmative. The problem, however, is with the notion of an "animal variety," which seems to be much more difficult to define both on a legal and a scientific basis, than with that of a "plant variety." Yet this issue is critical for it is this distinction which draws the dividing line between patentable and non-patentable animal kingdom inventions in Europe. In the absence of any practice, it is impossible to foresee what approach could be chosen by the EPO in the future. It is not known whether it will be influenced by the legal term of "variety" as applied in breeders' right systems, or if it will try to solve the problem scientifically. In Switzerland the Federal Office for Intellectual Property in its Examination Guidelines, as amended in March $1986,{ }^{6}$ has chosen the first alternative by generally drawing a parallel to plant varieties, as defined in Swiss Plant Variety Law (SR 232.16). According to No. 3.3 of the Swiss Examination Guidelines, in connection with No. 3.2, one can assume that product claims directed to whole animal species and genera (e.g. a mouse) are allowed, as well as claims directed to animal material, be it either propagating material in which a variety is not yet fixed" or "building blocks" such as animal cell lines, modified cells, genes, or plasmids, which are not capable of regenerating into whole animals. The problem remains: when can an animal with new characteristics be viewed as distinguishable from others while being stable and homogeneous enough so as to form a new animal variety? Simple parallelism with plant varieties does not seem appropriate and possible (Teschemacher, 1987: p. 98). Doubts may also be expressed as to whether science could help lawyers in this area. If an animal variety (race) is understood as including (Kruger, 1961: p. 25; Herre, 1961: p. 2):

Those animals of a given species that-whilst having the same genetic traits-differ from all the other animals of the same species and-by the means of these genetic traits (characteristics)-can be viewed as a population.

and

Varieties (races) are open genetic populations within the closed genetic population of a species and can undergo changes more rapidly than species.

This does not really solve the problem that we are faced with.

7 In the sense of being distinguishable from other varieties, homogeneous, and stable. 
Under the case law of the EPO Board of Appeals, exclusions from patentability in the EPC must be narrowly construed. ${ }^{8}$ Following this rule of interpretation, EPC product protection should, in principle, be available for most results of modern animal biotechnology along the lines indicated by the Swiss Examination Guidelines, beginning with animal biological material of all kinds, such as genes, transfer vectors, cell lines, modified cells, etc., and ending with transgenic animals (Moufang, 1988: p. 215). In other words, in my understanding of Articles 53(a) and 53(b), in principle, all twelve claims of the US Leder patent for "transgenic non-human mammals" should be allowable. 9 The same should apply for the invention of "transgenic animals secreting desired proteins into milk," which is also pending at the EPO,${ }^{10}$ because none of the claims of concern is directed to a specific "animal variety."11 Furthermore, such transgenic animals as the newly reported quail chick chimeras should be viewed as, in principle, patentable subject matter (Balaban et al., 1988; Barnes, 1988).

The words "in principle" are used here to indicate that all the product claims mentioned may well face some problems: for instance, the problem of the enabling written disclosure according to Article 83 of the EPC, ${ }^{12}$ which in many animal biotechnology inventions could presumably be met only by a deposit of pertinent animal material in a depository as provided for in Rule 28 and 28(a) of the EPC. Although the deposit of animal genes, plasmids, and cells and cell lines should not, as a rule, produce any specific problems, it is at present completely uncertain whether any animal propagating material deposit, if technically practicable, would be accepted under the EPC and the harmonized European patent laws (Savignon, 1985: p. 85; Straus, 1985: para. 94; von Pechmann, 1987: p. 486).

Because of the possible problems of enabling written disclosure, and taking into account possible negative effects of the release of deposited material, the importance of claims based upon modern biotechnological processes becomes evident. Recent advances in genetic engineering have considerably improved the ability of inventors to disclose in sufficient detail the methods employed. This fact, combined with the language of Article 53(b) of the EPC, clearly favors the modern animal biotechnologists over traditional animal breeders. As already noted, Article 53(b) declares that "essentially biological processes" for the production of animals are unpatentable, but at the same time it explicitly allows protection for microbiological processes in general, and implicitly allows for non-biological

8 Technical Board of Appeals 3.3.1 of March 27, 1986, 1986 Off. J. EPO, 301 (at 304)Appetite suppressant/DUPONT; see also decision of the Technical Board of Appeals of July 26, 1983, 1984 Off. J. EPO, 112 (at 116)-Propagating Material/CIBA-GEIGY.

9 US Patent no. 4,736,866 (issued April 12, 1988).

10 EP publication no. 0264166-A 1 (April 20, 1988).

11 Neither the rodent of claim 11 nor the "rodent being a mouse" of claim 12 in the Leder patent can be viewed as an animal variety.

12 Article 83: "The European Patent Application must disclose the invention in a manner sufficiently clear and complete for it to be carried out by a person skilled in the art." 
processes for the production of animals. According to the EPO Examination Guidelines (Part C-IV 3.4):

The question whether a process is "essentially biological" is one of degree depending on the extent to which there is technical intervention by man in the process; if such intervention plays a significant part in controlling the result it is desired to achieve, the process would not be excluded.

As examples of essentially biological processes the Guidelines enumerate methods of crossing, interbreeding or selectively crossing (EPO Examination Guidelines, Part C-IV 3.4). It is commonly understood that any method of genetic engineering (e.g. recombinant DNA, microinjection, etc.) is regarded as being "non-biological" (i.e. technical in character) (Beier and Straus, 1986: p. 456; Teschemacher, 1987: p. 95; von Pechmann, 1987: p. 348). When, in a process for the production of animals, biological as well as technical elements are present, then, as Teschemacher has correctly pointed out, one has to find out where the core of the invention lies. In other words, it has to be determined whether the human intervention plays only a supporting or a determining role in the invention. If the product could not have been created naturally, the human intervention was decisive. It is clear that some examples of that art, especially when multistep processes are involved, can create problems. For example, the method of inducing polyploidy in Pacific oysters of the species Crassostrea gigas in ex parte Allen could have presented a borderline case ${ }^{13}$ In my opinion, however, the steps of inducing oysters to spawn, the fertilizing of the eggs with sperm to form zygotes, and, especially, the applying of hydrostatic pressure to zygotes at a predetermined intensity for a predetermined duration after a predetermined time following formation of zygotes to induce polyploidy made human intervention the determining or controlling factor in producing the desired result. As a consequence, the method of producing these oysters is patentable in the sense of the EPO Examination Guidelines.

\section{UNRESOLVED PROBLEMS UNDER THE EPC}

Notwithstanding the general attitude of the EPO to interpret exclusionary provisions as restrictively as possible and to grant the broadest possible protection, a number of questions raised by the language of Article 53(b) of the EPC remain unclarified. This is specifically true for the necessary application of the notions of "microbiological" or "essentially biological" processes, as well as of "animal varieties." These form a grey area and represent a factor of constant uncertainty. Although the EPO Examination Guidelines offer some reasonable solutions, application is faced with 
difficulties, and the final outcome of patents granted in this area is uncertain.

Less satisfying and clear are the areas not covered by the EPC, namely scope or extent and exhaustion of protection. Until the competent courts of contracting states resolve such questions as how to interpret the notion of "products directly obtained by a process," inventors and industries will remain without any reliable guidance as to the purposefulness of their investments. The scope of protection is of decisive importance for determining the value of process patents in this area, and until now it is a point of controversy in the literature (Moufang, 1988: pp. 382-3). A similar statement can be made regarding the exhaustion of rights conferred by a product patent (e.g. for an animal gene inserted into a host organism and transferred to its progeny) (Moufang, 1988: pp. 384-5).

\section{APPROACH OF THE EEC COMMISSIONS}

Although the potential to protect biotechnological inventions under the EPC cannot be claimed as particularly bad,${ }^{14}$ the procedures clearly fall short compared with those available in the USA. But the overall situation in Europe is far worse if one takes into account the fact that not all EEC member states are party to the EPC and that the practice of EPO could well be questioned by national courts when deciding on infringement and revocation of European patents. Widely differing outcome of national case law could also be imagined in respect to the scope and extent of the rights conferred by European patents.

In order to establish harmonized, clear, and improved patentability standards as well as greater certainty regarding the scope of protection, the Commission of the European Communities presented a Proposal for a Council Directive on the Legal Protection of Biotechnological Inventions on October 17,1988 . This draft directive will, no doubt, be the main object of discussions among governments and interested circles in the near future. Since it is of decisive importance also for inventions in animal biotechnology, I shall try to introduce briefly its main characteristics, as well as some provisions of specific interest.

The main characteristic, but possibly also the main handicap, of the draft is its intention not to interfere with exclusionary provisions existing under the EPC and the national patent laws. It is aimed at establishing as narrow an application of those provisions as possible on the one hand, as well as a firm and appropriate scope of protection on the other. A more radical approach, which would certainly make the life of patent lawyers easier and would be welcomed especially in the field of animals, did not seem feasible for political reasons. Although the proposed directive neither directly nor legally affects

14 It has to be noted, however, that possible negative positions of the EPO towards patenting in specific fields are controlled only by its Board of Appeals, which is deciding in the last instance. Applicants are so far facing a quite badly balanced system. For details see Beier (1989). 
either the EPC or the practice under the EPC, it will indirectly have substantial effects in both areas. By means of correlation with the existing patentgranting practice based on the EPO Examination Guidelines and by providing for solutions to problems not yet resolved in the Examination Guidelines of the EPO, the directive is aimed at supporting the EPO in its ongoing efforts to establish its Examination Guidelines (Directive, Part 1, para. 40-46) on a firmer basis.

As regards the patentability of products of animal biotechnology, the draft directive ensures the patentability of living matter in general and clarifies the point that any exclusion of animal varieties shall not extend to the patenting of parts of animal varieties. Claims for classifications higher than varieties (e.g. for species, genera, etc.) are allowable (Article 3(1)), as are patents for uses of animal varieties and processes for the production thereof (Article 4).

Definitions clarifying expressions such as "microbiological process" or "essentially biological process" are of great value. According to Article 5, "a microbiological process is one which is carried out with the use of or is performed upon or resulting in a microorganism." In addition, a process consisting of a succession of steps is regarded a microbiological process if the essence of the invention is incorporated in one or more microbiological steps of the process (Article 6). A process in which human intervention consists of no more than selecting between available biological material and letting it carry out an inherent biological function under natural conditions is not regarded as essentially biological (Article 7). Finally, the draft directive clarifies that surgical or diagnostic methods practiced on an animal body are excluded from patent protection only if practiced for a therapeutic purpose (Article 18). Thus such methods as embryo recovery and transfer employed for animal production should be patentable in the European Community member states in the future.

Provisions concerning the scope of protection incorporate the introduction of the clear rule that process protection of self-replicable matter extends to the identical or differentiated products of first as well as of subsequent generations, notwithstanding the fact that such products may be excluded from patent protection as such (Article 12). In other words, the draft directive provides explicitly for the protection of animals and animal varieties produced by a patented method (e.g. genetic engineering) and extends such protection to products of subsequent generations. Moreover, protection for a product comprising or consisting of genetic information (e.g. a gene coding for a specific animal trait) as an essential characteristic of the invention is extended to any products in which that genetic information has been incorporated and is of essential importance for its industrial applicability or utility (Article 13; Directive Part 2). For the sake of completeness, it should be added that the draft directive is also introducing the reversal of the burden of proof in cases of infringement of process patents for obtaining new as well as known products. This provision of Article 17 could play an important role in the field of animal biotechnology. 


\section{CONCLUSIONS}

With regard to the scientific development in the field of interest, in Europe there is a situation comparable with that in the USA. With regard to the ability of the courts and legislation to react to new technological developments, the differences are considerable. Whereas both the courts and legislation of the European Community member states are preempted or bound either by narrow limits of the law or by existing, expressed or assumed international obligations, ${ }^{15}$ US legislation, courts, and administration do not have such constraints. Scientific achievements in modern animal biotechnology, the exclusionary provisions of the EPC and harmonized national patent laws do prevent patenting of traditional animal-breeding results, but do so while allowing the patenting of all kinds of animal material and of transgenic animals, as long as claims are not directed to animal varieties. For the time being, the situation has not been clarified by the courts or by patent office practice. The national patent offices, as is the case of the EPO, are hesitant to exploit existing opportunities. The adoption of the European Community draft directive would improve the situation considerably and make the legal status of European law comparable to that of the USA.

\section{References}

Adler, R. G. (1986) Can Patents Coexist with Breeders' Rights? Developments in US and International Biotechnology Law. Int. Rev. Ind. Property Copyright Law, 17: 195-227.

Balaban, E., M.-A. Teillet, and N. LeDouarin (1988) Application of the QuailChick Chimera System to the Study of Brain Development and Behaviour. Science, 241: 1339 et seq.

Barnes, D. (1988) Bird Brain Switch Leads to New Song. Science, 241: 1434.

Beier, F. K. (1984) Das europäische Patentsystem. Europäisches Patentübereindommen, ed. Beier, Haertel, and Schricker. Münchner Gemeinschaftskommentar, Cologne.

(1989) Die Rechtsbehelfe des Patentanmelders und seiner Wettbewerber im Vergleich: eine rechtsvergleichende Untersuchung zur Chancengleichheit im Patentverfahren. GRUR Int: : 1 et seq.

Beier, F. K., R. S. Crespi, and J. Straus (1985) Biotechnology and Patent Protection: An International Review. Paris: OECD.

Beier, F. K. and J. Straus (1986) Genetic Engineering and Industrial Property. Ind. Prop., 11: 447-9.

Benkard, G., K. Bruchhausen et al. (1988) Patentgesetz, Gebrauchsmustergesetz, 8th edn. Munich: C. H. Beck Verlag.

Bent, S. A., R. L. Schwaab, D. G. Conlin, and D. D. Jeffery (1987) Intellectual Property Rights in Biotechnology Worldwide. New York: Stockton Press.

Board on Agriculture, National Research Council (1984) Genetic Engineering of

15 The exclusion of animal varieties and essentially biological processes for the production of animals as introduced in national laws of European countries does not directly result from any international treaty. 
Plants-Agricultural Research Opportunities and Policy Concerns. Washington, DC. Brem, G. (1988a) Aspects of the Application of Gene Transfer as a Breeding Technique for Farm Animals. Biologisches Zentralblatt, 108: 1-8.

(1988b) The Development of Gene Transfer in Farm Animals. Pro Veterinario, 8 (Feb.): 1 et seq.

Brem, G., B. Brenig, H. M. Goodman, R. S. Selden, F. Graf, B. Kruff, K. Springmann, Hondele, J. Meyer, E. L. Winnacker, and Kräusslich (1986) Gene Transfer in Rabbits and Pigs, 3rd World Congress of Genetics Applied to Livestock Production, July 16-22, 1986, Lincoln, Nebraska, Part XII, p. 45 et seq.

Brem, G., B. Brenig, G. Hörstgen-Schwark, and E. L. Winnacker (1988) Gene Transfer in Tilapia (Oreochromis niloticus). Aquaculture, 68: 209 et seq.

Clark, A. J., J. P. Simons, I. Wilmut, and R. Lathe (1987) Pharmaceuticals from Transgenic Livestock. Trends Biotec, 5: 20 et seq.

Clark, R. W. (1985) The Life of Ernst Chain: Penicillin and Beyond. London: Weidenfeld and Nicolson, p. 56.

Commission of the European Communities (1988) Proposal for a Council Directive on the Legal Protection of Biotechnological Inventions. COM (88) 496 final-SYN 159, Brussels, Oct. 17, 1988.

Committee on a National Strategy for Biotechnology in Agriculture, National Research Council (1987) Agricultural Biotechnology: Strategies for National Competitiveness, Washington DC.

Cooper, I. P. (1985) Biotechnology and the Law, 2nd edn. New York: Clark Boardman.

Herre, W. (1961) Der Art- und Rassebegriff. Handbuch der Tierzüchtung, ed. J. Hammond et al. Hamburg: Parey.

Jaenisch, R. (1988) Transgenic Animals. Science, 204 (June): 1468 et seq.

Krüger, L. (1961) Geschichtliche Entwicklung der Rassen in der europäischen Tierzucht. Handbuch der Tierzüchtung, ed. J. Hammond et al. Hamburg: Parey.

Land, R. B. and I. Wilmut (1987) Gene Transfer and Animal Breeding. Theriogeneology, 27 (Jan.): 169 et seq.

Lesser, W. (1987) Applying Animal Patents in Agriculture: Lessons for Farmers and the Patent Office for Self-Reproducible Animals. World Intellectual Property Organization, Proceedings, Symposium on the Protection of Biotechnological Inventions, June 4-5, 1987, Ithaca, NY, pp. 134-54.

- (1988) Animal Patents in the USA: Are the Concerns Justified? Lecture given at World Intellectual Property Organization, Geneva, Sept. 1988.

McEvoy, T. G., M. Stack, T. Barry, B. Keane, F. Gannon, and J. M. Sreenan (1987) Direct Gene Transfer by Microinjection. Theriogeneology, 27 (Jan.): 258 et seq.

Moufang, R. (1988) Genetische Erfindungen im gewerblichen Rechtsschutz. Cologne: Heymans.

Patent, Trademark and Copyright Journal (1988a) House Passage of Animal Patent Bill (HR 4970). 36 (Sept. 15): 499-502.

- (1988b) House Judiciary Committee Report on HR 4970. 36 (Sept. 15): 503-542.

Pretnar, S. (1982) Inventors' Certificates, Rationalization Proposals and Discoveries. Copyright and Industrial Property, International Encyclopedia of Comparative Law, vol. 14. Tübingen: J. C. B. Mohr (Paul Siebeck).

Raines, L. J. (1988) The Mouse That Roared. Iss. Sci. Technol., 70 (summer): 64 et seq.

Ruttan, V. W. (1982) Agricultural Research Policy. Minneapolis: University of Minnesota Press.

Savignon, F. (1985) Die Natur des Schutzes der Erfindungspatente und seine Anwendung auf lebende Materie, GRUR Int: 83 et seq.

Straus, J. (1984) Patent Protection for New Varieties of Plants Produced by Genetic 
Engineering: Should “Double Protection” Be Prohibited? Int. Rev. Ind. Property Copyright Law, 15: 426 et seq.

(1985) Industrial Property Protection of Biotechnological Inventions, Analysis of Certain Basic Issues. Geneva: World Intellectual Property Organization, BIG 281 (July).

(1987) The Principle of "Dependence" under Patents and Plant Breeders' Rights. Ind. Prop., 12: 433 et seq.

Teich, A. M. et al. (eds.) (1985) Biotechnology and the Environment. Washington DC: AAAS.

Teschemacher, R. (1987) Patentable Subject Matter under the European Patent Convention (EPC) in the Field of Biotechnology. World Intellectual Property Organization, Proceedings, Symposium on the Protection of Biotechnological Inventions, June 4-5, 1987, Ithaca, New York, p. 87 et seq.

UPOV (1987) Possible Consequences of Biotechnology in the Field of Intellectual Property Protection. Doc. IOM/III/2 (July 9), p. 7, para 9.

von Pechmann, E. (1987a) Ausschöpfung des bestehenden Patentrechts für Erfindungen auf dem Gebiet der Pflanzen- und Tierzüchtung unter Berücksichtigung des Beschlusses des Bundesgerichtshofs-Tollwutvirus. GRUR Int.: 475 et seq.

(1987b) Ist der Ausschluss von Tierzüchtungen und Tierbehandlungsverfahren vom Patentschutz gerechtfertigt? GRUR Int.: 344-7. 